\title{
ATTEIKŠANĀS NO MILITĀRĀ DIENESTA IZPILDES PACIFISMA VAI PRINCIPIĀLU IEBILDUMU DĒL,
}

\section{REFUSAL TO PERFORM MILITARY \\ SERVICE DUE TO PACIFISM OR PRINCIPLED OPPOSITION}

\author{
Viktorija Katajeva, Mg. iur. \\ Latvijas Universitātes Juridiskās fakultātes doktorante
}

\begin{abstract}
Summary
The purpose of the article is twofold: to determine whether the legal provisions of the Military Service Law contain restrictions of the refusal to perform military service due to pacifism or principled opposition; and to estimate whether such restrictions of fundamental rights are justified. The author concludes that the existing regulation does not comply with the principle of proportionality and thereby can be recognized as unjustifiable violation of the right to freedom of thought, conscience and religion.
\end{abstract}

Atslēgvārdi: militārais dienests, pacifisms, principiāli iebildumi.

Keywords: military service, pacifism, principled opposition.

\section{Ievads}

2020. gada nogalē Saeima apstiprināja Valsts aizsardzības koncepciju1, kurā citā starpā ir norādīts, ka, lai arī valsts aizsardzība attiecas uz ikvienu Latvijas iedzīvotāju, tieši Nacionālie bruṇotie spēki (turpmāk - NBS) ir šīs aizsardzības stūrakmens. $^{2}$

NBS īstenotās valsts aizsardzības funkcijas efektīva realizācija visupirms ir atkarīga no militārās aizsardzības sistēmas, proti - militārā dienesta un tā izpildes kvalitātes. Nav šaubu, ka militārā dienesta attiecību pamatā ir valsts imperatīvās militārās intereses, savukārt tā izpildes kvalitāte galvenokārt ir atkarīga no cilvēkresursiem. Tāpat nav šaubu, ka šo vitālo valsts interešu efektīva nodrošināšana ir pamatā tam, ka iesaistīto cilvēku pamattiesības var tikt ierobežotas. Tomēr demokrātiskā tiesiskā valstī nav piẹ̦aujami pamattiesību neattaisnojami aizskārumi. Šā raksta mērḳis ir noskaidrot, vai militārā dienesta tiesiskajā regulējumā ir noteikti ierobežojumi attiecībā uz atteikšanos no šāda dienesta izpildes pacifiskās

\footnotetext{
${ }^{1}$ Valsts aizsardzibas koncepcija. Pieejams: https://likumi.lv/ta/id/317591-par-valsts-aizsardzibas-koncepcijas-apstiprinasanu [aplūkots 23.02.2021.].

2 Turpat, 3.1. apakšpunkts.
} 
pārliecības vai principiālu iebildumu dēḷ, un izvērtēt, vai šādi pamattiesību ierobežojumi ir attaisnojami visos noteiktajos gadījumos.

\section{Pacifisma un principiālu iebildumu jēdziens}

Ārvalstu akadēmiskajā literatūrā tiek norādīts, ka mūsdienās jēdzienam "pacifisms" ir vairākas nozīmes un kategorijas. ${ }^{3}$ Tas tiek izmantots, lai apzīmētu pasaules redzējumu, kas nosoda jebkura veida vardarbību, personas morālo nostāju (pozīciju) un sabiedrisku kustību, kas propagandē kara amorālo dabu, kā arī ideologiiju par vispārēju mieru. ${ }^{4}$ Nemot vērā šā raksta mērķi, tajā pacifisms tiks skatīts tikai tā morālās attieksmes nozīmē, kā individuāla atteikšanās iesaistīties un piedalìties bruṇotajos konfliktos un militārajās aktivitātēs arī miera laikā, pildīt militāro dienestu, kā arī lietot spēku, tai skaitā - nesāt un izmantot ieročus.

Pacifiskās pārliecības un principiālu iebildumu pret militārā dienesta izpildi jēdziens nav nedz lietots Latvijas normativajos aktos, nedz analizēts mùsdienu Latvijas tiesību doktrīnā. Tomēr šādi jēdzieni tika vērtēti un to saturs atklāts Eiropas Cilvēktiesību tiesas un Eiropas Cilvēktiesību komisijas praksē. ${ }^{5}$ 1982. gadā Eiropas Cilvēktiesību tiesa atzina, ka termins "pārliecība" Cilvēka tiesību un pamatbrīiību aizsardzības konvencijas ${ }^{6}$ (turpmāk - Konvencija) 9. panta kontekstā nav sinonīms vārdiem "viedoklis” un "ideja”, tas apzīmē uzskatus, kas sasniedz zināmu pārliecības, nopietnības, saliedētības un nozīmīguma lìmeni. ${ }^{7}$ Savukārt 1996. gadā Eiropas Cilvēktiesību tiesa, atsaucoties uz Eiropas Cilvēktiesību komisijas praksi ${ }^{8}$, norādija, ka pacifisms kā filozofija ietilpst tiesību uz domas un pārliecības brīvību jomā, un tāpēc personas pacifisko attieksmi var uzskatīt par apziṇu (pārliecību), ko aizsargā Konvencijas 9. panta ${ }^{9}$ pirmā daḷa. ${ }^{10}$ Principiālu iebildumu jēdzienu savā praksē Eiropas Cilvēktiesību tiesa vērtēja 2011. gadā, norādot, ka Konvencijas 9. pants aizsargā tiesības iebilst pret militāro dienestu, ja šādu iebildumu pamatā ir nopietns un nepārvarams konflikts starp pienākumu dienēt armijā un personas sirdsapziṇu vai tās dziḷi un patiesi pastāvošo reliğisko vai citu pārliecību. ${ }^{11}$ Tādējādi no Eiropas Cilvēktiesību tiesas judikatūras izriet,

${ }^{3}$ Fiala A. Pacifism. The Stanford Encyclopedia of Philosophy. Pieejams: https://plato.stanford.edu/archives/ fall2018/entries/pacifism/ [aplūkots 23.02.2021.].

4 Васильев А. В. Пацифизм. Энциклопедия Всемирная история. Pieejams: https://w.histrf.ru/articles/ article/show/patsifizm [aplūkots 23.02.2021.]. Sk. arī: Коллектив авторов. Пацифизм в истории. Идеи и движения мира. Pieejams: http://www.fedy-diary.ru/library-pages/auditorium-n-f-bugaj-20-50-egody-pereseleniya-i-deportacii-evrejskogo-naseleniya-v-sssr/pacifizm-v-istorii-idei-i-dvizheniya-mirachast-i/ [aplūkots 23.02.2021.].

${ }^{5}$ Latvijas tiesu praksē jēdzieni ar atsaucēm uz ECT praksi tika apskatīti Rīgas apgabaltiesas 06.03.2020. spriedumā lietā Nr. A420200818, 16. p. Pieejams: https://manas.tiesas.lv/eTiesasMvc/lv/nolemumi [aplūkots 23.02.2021.].

${ }^{6}$ Cilvēka tiesību un pamatbrīvību aizsardzības konvencija. Parakstīta Romā 04.11.1950. [24.02.2021. red.].

7 ECT 25.02.1982. spriedums lietā Campbell and Cosans pret Apvienoto Karalisti (iesnieguma Nr. 7511/76; 7743/76), para. 36.

${ }^{8}$ Eiropas Cilvēktiesību komisijas 12.10.1978. ziṇojums lietā Arrowsmith pret Apvienoto Karalisti (iesnieguma Nr. 7050/75), para. 69

9 Sỉkāk par konvencijas 9. panta tvērumu sk.: Guide on Article 9 of the Convention - Freedom of thought, conscience and religion. Pieejams: https://www.echr.coe.int/Documents/Guide_Art_9_ENG.pdf [aplūkots 24.02.2021.].

10 ECT 18.12.1996. spriedums lietā Valsamis pret Grieķiju (iesnieguma Nr. 21787/93), para. 21.

11 ECT 07.07.2011. spriedums lietā Bayatyan pret Armēniju (iesnieguma Nr. 23459/03), para. 110. 
ka pacifiskā pārliecība un principiāli (noturīgi) iebildumi pret militārā dienesta izpildi ietilpst Konvencijas 9. panta tvērumā.

\section{Militārais dienests un pamattiesību ierobežojumi tā tiesiskajā regulējumā}

Nacionālo bruṇoto spēku personālsastāva komplektēšanu un militārā dienesta gaitu reglamentē speciāls likums - Militārā dienesta likums ${ }^{12}$, kas noteic, ka militārais dienests ir valsts dienesta veids valsts aizsardzības jomā, kuru pilda karavīrs un kurš ietver aktīvo dienestu un dienestu NBS rezervēe ${ }^{13}$. Tātad militārais dienests Latvijā sastāv no diviem vitāli atšķirīgiem, bet savstarpēji saistītiem apakšdienestiem - aktīvā dienesta un dienesta NBS rezervē.

Saskaṇā ar Militārā dienesta likuma 2. panta 2. punktu aktīvais dienests ir militārā dienesta tieša izpilde karavīra statusā, kas ietver profesionālo dienestu, militārā dienesta tiešu izpildi mobilizācijas gadījumā un rezerves karavīru militārās mācības. Tas nozīmē, ka tiesiskajā regulējumā ietvertie pamattiesību ierobežojumi tiks attiecināti ne vien uz ìpašā tiesiskajā statusā esošajām personām - profesionālā dienesta karavīriem ${ }^{14}$, kuri šādu dienesta izvēlējās un pilda brīvprātīgi, bet arī uz personām, kas ir pakḷautas mobilizācijai, proti, arī uz rezervistiem.

Militārā dienesta likumā expressis verbis nav noteikti ierobežojumi aktīvā dienesta karavīram atteikties no militārā dienesta izpildes pacifiskās pārliecības vai principiālu iebildumu dẹlı. Tomēr šā likuma 15. panta otrā daḷa imperatīvi noteic, ka karavīram nav tiesību atteikties no dienesta izpildes religisku motīvu dēḷ. N̦emot vērā likuma teleologisko dabu, kā arī Satversmes tiesas judikatūrā minēto, proti, ka reliǵijas brīvība ir viens no demokrātiskas sabiedrības stūrakmeñiem ${ }^{15}$ un viena no nozīmīgākajām vērtībām demokrātiskā sabiedrībāi ${ }^{16}$, autore izdara slēdzienu par apjomu. Konkrētajā gadijjumā - kā slēdziens no lielākā uz mazāko (argumentum a maiori ad minus) - ja aizliegums ir paredzēts attiecībā uz reliǵgisko pārliecību, vēl jo vairāk tas ir attiecināms uz pacifisko pārliecību un principiāliem iebildumiem - likumā tieši nenoregulēto gadījumu.

Otrs militārā dienesta veids ir dienests NBS rezervē, kas atbilstoši Militārā dienesta likuma 2. panta $2 .{ }^{1}$ punktam ir rezerves karavīram noteikto pienākumu izpilde. Arī šajā gadījumā Militārā dienesta likumā expressis verbis nav iekḷauti ierobežojumi rezerves karavīram atteikties no ieskaitī̌sanas un pienākumu izpildes militārā dienesta rezervē pacifisma vai principiālu iebildumu dēḷ. Tomēr attiecībā uz dienestu NBS rezervē Militārā dienesta likuma 15. panta otrā daḷa nav piemērojama, tāpēc arī nav iespējams izdarīt slēdzienu par apjomu.

Atbilstoši Militārā dienesta likuma 63. pantam dienestam NBS rezervē var pieteikties brīvprātīgi, tomēr primāri šāda tiesību norma regulē obligātu dienesta izpildes pienākumu konkrētam subjektu lokam, piemēram, atvaḷinātajiem no

\footnotetext{
12 Militārā dienesta likums: LV likums. Pieņemts 30.05.2002. [25.02.2021. red.].

13 Turpat, 2. panta 1. punkts.

${ }^{14}$ Noslēdzot profesionālā dienesta līgumu, tiek nodibinātas militārā dienesta tiesiskās attiecības, kuru ietvaros karavīrs atrodas īpašā valsts pakḷautībā - NBS rīcībā. Sīkāk par karavīru īpatnējo tiesisko stāvokli sk.: Dišlers. K. Ievads administratīvo tiesību zinātnē. Rīga: Tiesu namu aǵentūra, 2002, 144. lpp.

15 Satversmes tiesas 26.04.2018. spriedums lietā Nr. 2017-18-01, 18. p. Latvijas Vēstnesis, 2018, Nr. 85.

16 Satversmes tiesas 18.03.2011. spriedums lietā Nr. 2010-50-03, 7.1. p. Latvijas Vēstnesis, 2011, Nr. 45.
} 
profesionālā dienesta karavīriem un zemessargiem pēc līguma par dienestu Zemessardzē izbeigšanas, nepiel̦aujot izņēmumus un individuālu izvērtēšanu, kuru pamatā būtu relig̣iskās vai citas pārliecības aspekti. N̦emot vērā speciāla likuma 68. pantu kopsakarā ar 42. panta otro daḷu, jāsecina, ka likumdevējs šajās normās paredzēja un precīzi uzskaitīja apstākḷus un gadījumus, kad rezerves karavīru noņem no militārā dienesta uzskaites, - pacifiskā pārliecība un principiāli iebildumi pret militāro dienestu nav starp šiem izsmel̦ošiem gadījumiem.

Tādējādi, sistēmiski un teleoloǵiski tulkojot militārā dienesta normatīvo regulējumu, kā arī lietojot tiesību tālākveidošanu, autore secina, ka Militārā dienesta likumā gan aktīvā dienesta karavīram, gan rezerves karavīram ir noteikti ierobežojumi atteikties no dienesta izpildes pacifisma vai principiālu iebildumu dēl, turklāt šādi ierobežojumi ir vērtējami kā vispārēji jeb absolūti aizliegumi ${ }^{17}$, jo pastāv neierobežotu laiku un attiecas uz visiem karavīriem, neparedzot individuālu gadījumu izvērtējumu.

N̦emot vērā militārā dienesta pamatā esošās valsts imperatīvās militārās intereses, likumdevējs var tā tiesiskajā regulējumā ietvert pamattiesību ierobežojumus atteikšanās no dienesta izpildes aspektā, tai skaitā - absolūtus aizliegumus, tomēr likumdevējam ir jāpārliecinās un jāpamato, ka šādi ierobežojumi ir ne vien nepieciešami, bet arī attaisnojami katrā konkrētajā gadījumā.

\section{Satversmes 99. panta pirmajā teikumā ietverto pamattiesību ierobežojumu attaisnojamiba}

Pārbaudi, vai likumdevēja noteiktais pamattiesību ierobežojums ir attaisnojams, autore veiks trijos soḷos - pirmkārt, tiks konstatēts pamattiesības tvērums, otrkārt - vai valsts rīcība ir kvalificējama kā šīs pamattiesības aizskārums, un, treškārt - vai šis aizskārums ir attaisnojams. ${ }^{18}$

Satversmes 99. panta pirmajā teikumā ir ietvertas personas tiesības uz domas, apziņas un reliǵiskās pārliecības brīvību. Satversmes tiesa līdz šim ir interpretējusi Satversmes 99. panta ietvaru divās lietās ${ }^{19}$, sniedzot atziṇas tikai par vienu šīs pamattiesības elementu - reliǵgisko pārliecību, norādot, ka reliǵiskās pārliecības iekšējais aspekts tiek nošķirts no brīvības ārējās izpausmes - tās paušanas. Savukārt tiesību doktrīnā tiek minēts, ka 99. panta aizsardzība pamatā ir attiecināma uz reliǵijas brīvību, proti, politisku, pacifistisku un citu uzskatu paušanu (manifestāciju) sargā citi Satversmes panti. ${ }^{20}$

Atklājot Satversmes 99. panta saturu, jāṇem vērā arī starptautiskie cilvēktiesību dokumenti un to piemērošanas prakse, jo Satversmes 89. pants skaidri norāda uz konstitucionālā likumdevēja mērḳi panākt Satversmē ietverto cilvēktiesību normu

17 Sīkāk par absolūta aizlieguma jēdzienu sk.: Katajeva V. Noziedzīga nodarījuma izdarīšana kā absolūts aizliegums pieņemšanai militārajā dienestā. Grām.: Starptautisko un Eiropas Savienības tiesību piemērošana nacionālajās tiesās. Latvijas Universitātes 78. starptautiskās zinātniskās konferences rakstu krājums. Rīga: LU Akadēmiskais apgāds, 2020, 495.-501. lpp.

18 Sk.: Levits E. Cilvēktiesību piemērošanas pamatjautājumi Latvijā. Grām.: Cilvēktiesības Latvijā un pasaulē. I. Ziemeles redakcijā. Rīga: Izglīīibas soḷi, 2000, 280. lpp.

19 Satversmes tiesas 18.03.2011. spriedums lietā Nr. 2010-50-03; Satversmes tiesas 26.04.2018. spriedums lietā Nr. 2017-18-01.

20 Balodis R. 99. panta komentārs. Grām.: Latvijas Republikas Satversmes komentāri. VIII nodal̦. Cilvēka pamattiesības. Autoru kolektīvs prof. R. Baloža zinātniskā vadībā. Rīga: Latvijas Vēstnesis, 2011, 320. lpp. 
harmoniju ar starptautiskajām cilvēktiesību normām. ${ }^{21}$ Satversmes 99. pantam līdzīga norma ir ietverta Konvencijas 9. pantā. Konvencijas 9. panta pirmais teikums noteic, ka ikvienam cilvēkam ir tiesības uz domu, apziṇas un reliğijas brīvību. Kā jau iepriekš tika secināts, Eiropas Cilvēktiesību tiesa atzina, ka pacifiskā pārliecība un principiāli (noturīgi) iebildumi pret militārā dienesta izpildi ietilpst Konvencijas 9. panta tvērumā. Ievērojot iepriekš minēto, jāsecina, ka pacifiskā pārliecība un principiāli iebildumi pret militārā dienesta izpildi ietilpst Satversmes 99. panta tvērumā ${ }^{22}$, turklāt ierobežojama ir vienīgi to paušana - klusējot vai atsakoties veikt konkrētas darbības, kas ir pretrunā ar personas pārliecību.

Kad ir noskaidrots Satversmes 99. panta tvērums, ir jāizvērtē, vai šāda pamattiesība ir tikusi aizskarta. Par pamattiesību aizskārumu uzskatāms mērḳtiecīgs pamattiesību ierobežojums. ${ }^{23}$ No Militārā dienesta likuma minēto normu izstrādes un pieṇemšanas dokumentiem ${ }^{24}$ autore gūst apstiprinājumu, ka likumdevējs apzināti nav paredzējis iespēju aktīvā dienesta karavīram atteikties no militārā dienesta un rezerves karavīra tiesības tikt nonemtam no tā uzskaites karavīra iekšèjās pārliecības dēḷ. Atbilstoši tai personai nav pieņemami būt jebkādi saistītai ar NBS un pildīt likumā noteiktos karavīra pienākumus valsts militāro interešu labā. Militārā dienesta likuma regulējums skaidri norāda uz likumdevēja gribu paredzēt mērķtiecīgus ierobežojumus atteikties no militārā dienesta izpildes. Tādējādi ar likuma normās ietvertajiem absolūtiem aizliegumiem tiek ierobežotas personai Satversmes 99. panta pirmajā teikumā noteiktās tiesības uz domas, apziṇas un reliǵiskās pārliecības brīvību, proti, valsts rīcība ir kvalificējama kā pamattiesību aizskārums.

Vērtējot pamattiesību aizskāruma attaisnojamību, ir jāṇem vērā Satversmes tiesas praksē izveidoto pārbaudes metodologiju, kas paredz konkrētus ierobežojuma kumulativus pārbaudes kritērijus:

1) tas ir noteikts ar likumu;

2) tam ir leğitīms mērķis;

3) tas ir samērīgs. ${ }^{25}$

Militārā dienesta likums ir pieņemts normatīvajos aktos noteiktajā kārtībā, izsludināts un publiski pieejams atbilstoši normatīvo aktu prasībām. Lai arī aizliegumi atteikties no militārā dienesta izpildes pacifisma vai principiālu iebildumu dēl nav expressis verbis formulēti konkrētajā tiesību normā, tomēr likums (kā sistēma) ir pietiekami skaidrs, lai persona varētu izprast aizliegumu saturu un paredzēt tās piemērošanas sekas. Tādējādi pamattiesību aizskārums ir noteikts ar likumu.

Ikviena pamattiesību ierobežojuma pamatā ir jābūt apstākḷiem un argumentiem, kādēḷ tas vajadzīgs, proti, ierobežojums tiek noteikts svarīgu interešu leǵitīma mērḳa - labad. ${ }^{26}$ Satversmes 116. pants noteic, ka reliǵiskās pārliecības

\footnotetext{
${ }^{21}$ Satversmes tiesas 26.04.2018. spriedums lietā Nr. 2017-18-01, 18. p. Latvijas Vēstnesis, 2018, Nr. 85.

22 Šādu secinājumu izdarīja arī Rīgas apgabaltiesa spriedumā Nr. A420200818.

${ }^{23}$ Pleps J. 116. panta komentārs. Latvijas Vēstnesis, 2011, 769. lpp.

${ }^{24}$ Likumprojekta "Militārā dienesta likums" anotācija. Pieejams: http://helios-web.saeima.lv/bin/lasa? LP1062_0 [aplūkots 25.02.2021.]; Likumprojekta "Militārā dienesta likums" redakcija pirmajam lasījumam. Pieejams: http://helios-web.saeima.lv/bin/lasa?LP1062_0 [aplūkots 25.02.2021.]; Latvijas Republikas 7. Saeimas 2002. gada 30. maija pavasara sesijas četrpadsmitās sēdes stenogramma. Pieejams: http:// saeima.lv/lv/transcripts/view/754 [aplūkots 25.02.2021.]

25 Sk.: Satversmes tiesas 10.02.2017. spriedums lietā Nr. 2016-06-01, 21. p. Latvijas Vēstnesis, 2017, Nr. 33.

26 Satversmes tiesas 07.11.2013. spriedums lietā Nr. 2012-24-03, 17. p. Latvijas Vēstnesis, 2013, Nr. 220.
} 
paušanu var ierobežot likumā paredzētajos gadījumos, lai aizsargātu citu cilvēku tiesības, demokrātisko valsts iekārtu, sabiedrības drošību, labklājību un tikumību. Militārajam dienestam ir savas ievērojamas ippatnības, kas to būtiski atškirir no citiem valsts dienesta veidiem, - galvenokārt šāda īpatnība ir dienesta pamatā esošās valsts imperatīvās militārās intereses, kas vērstas uz valsts pastāvēšanas un suverenitātes nodrošināšanu. ${ }^{27}$ Valsts imperatīvo militāro interešu aizsardzība ir atkarīga no NBS gatavības, tai skaitā no pietiekamā karavīru skaita, nodrošināt ar valsts aizsardzỉbu un sabiedrības drošibu saistīto uzdevumu izpildi gan miera laikā, gan militāro draudu gadījumā. Iespējas atteikties no dienesta izpildes veicina NBS cilvēkresursu (karavīru) apjoma samazināšanos. Tādējādi Militārā dienesta likuma normās ietvertie absolūtie aizliegumi atteikties no dienesta izpildes pacifiskās pārliecības vai principiālu iebildumu dēl kalpo tādam mērḳim kā citu cilvēku tiesību un sabiedrības drošības aizsardzība.

Neievērojot samērīgumu, nevar nodrošināt taisnīgumu, kas ir demokrātiskas tiesiskas valsts tiesiskās sistēmas galīgais mērksis. ${ }^{28}$ Atbilstoši samērīguma principam būtiski privātpersonas tiesību vai tiesisko interešu ierobežojumi ir attaisnojami tikai ar nozīmīgu sabiedrības labumu. ${ }^{29}$ Nemot vērā, ka tiesībām uz domas, apziṇas un reliǵiskās pārliecības brīvību ir konstitucionālo tiesību rangs, absolūti aizliegumi šajās aspektā uzskatāmi par būtiskiem personas tiesību ierobežojumiem. No Satversmes tiesas judikatūras izriet, ka, izvērtējot absolūta aizlieguma samērīgumu papildus jau Satversmes tiesas praksē izstrādātajiem samērīguma kritērijiem, jāpārbauda arī tas, vai likumdevējs ir: 1) pamatojis absolūtā aizlieguma nepieciešamību; 2) izvērtējis absolūtā aizlieguma būtību un piemērošanas sekas; 3) pamatojis to, ka, paredzot izṇēmumus no šā absolūtā aizlieguma, pamattiesību ierobežojuma leǵitīmais mērḳis netiktu sasniegts līdzvērtīgā kvalitātē. ${ }^{30}$

No Militārā dienesta likuma minēto normu izstrādes un pieṇemšanas dokumentiem nevar gūt apstiprinājumu, ka likumdevējs analizēja un pamatoja absolūtā aizlieguma nepieciešamību attiecībā uz aktīvā dienesta karavīru vai rezerves karavīru. Arī rezervista tiesības tikt noņemtam no NBS rezerves uzskaites personas pacifiskās pārliecības vai principiālu iebildumu dēḷ netika vērtētas. Tas vien, ka likumdevējs apzināti nav paredzējis tiesiskajā regulējumā iespēju atteikties no militārā dienesta izpildes iekšējās pārliecības dēḷ, nenozīmē, ka likumdevējs šo apzinātu rīcỉbu ir pamatojis un izvērtējis tā būtību. Autore secina, ka likumdevējs cita starpā nav pamatojis, ka, paredzot izṇēmumus no vispārējā aizlieguma atteikties no militārā dienesta izpildes, pamattiesību ierobežojuma leǵitīmais mērḳis - citu cilvēku tiesību un sabiedrības drošîbas aizsardzība - netiktu sasniegts līdzvērtīgà kvalitātē. Ir pamatotas šaubas, ka sabiedrības labums no personas, kas atsakās valkāt karavīra formas tērpu, nēsāt un pielietot dienesta ieroci un citus militārus līdzekḷus, kas ir karavīra pamatpienākumi miera un militārā konflikta situācijās,

27 Augstākās tiesas Senāta Administratīvo lietu departamenta 04.06.2012. spriedums lietā Nr. SKA-138/2012, 12. p. Pieejams: http://www.at.gov.lv/lv/judikatura/judikaturas-nolemumu-arhivs/administrativo-lietudepartaments/ hronologiska-seciba?year=2012 [aplūkots 25.02.2021.].

28 Satversmes tiesas tiesneses D. Rezevskas atsevišķās domas lietā Nr. 2016-14-01 "Par Solidaritātes nodokḷa likuma 3., 5., 6., 7. un 9. panta atbilstību Latvijas Republikas Satversmes 91. panta pirmajam teikumam un 109. pantam", 3. p. Pieejams: http://m.likumi.lv/doc.php?id=295883 [aplūkots 01.03.2021.].

29 Augstākās tiesas Senāta Administratīvo lietu departamenta 03.10.2007. spriedums lietā Nr. SKA-376/2007, 14. p. Pieejams: http://www.at.gov.lv/lv/tiesu-prakse/judikaturas-nolemumu-arhivs/administrativo-lietudepartaments/klasifikators-pec-lietu-kategorijam/administrativais-process/tiesibu-principi/samerigumaprincips [aplūkots 01.03.2021.].

30 Satversmes tiesas 24.11.2017. spriedums lietā Nr. 2017-07-01, 19. p. Latvijas Vēstnesis, 2017, Nr. 234. 
ir lielāks par personas tiesībām nodarīto kaitējumu. Tādējādi Militārā dienesta likumā noteiktie absolūtie aizliegumi neatbilst samērīguma principam un līdz ar to atzīstami par Satversmes 99. panta pirmajā teikumā nostiprināto tiesību uz domas, apziṇas un relig̣iskās pārliecības brīvību neattaisnojamiem aizskārumiem.

\section{Kopsavilkums}

1. Militārā dienesta likumā gan aktīvā dienesta karavīram, gan rezerves karavīram ir noteikti ierobežojumi atteikties no dienesta izpildes pacifisma vai principiālu iebildumi dēḷ, turklāt šādi ierobežojumi ir vērtējami kā vispārēji aizliegumi, jo pastāv neierobežotu laiku un attiecas uz visiem karavīriem, neparedzot individuālu gadījumu izvērtējumu.

2. Militārā dienesta pamatā esošo valsts imperatīvo militāro interešu aizsardzībai likumdevējs var tā tiesiskajā regulējumā ietvert pamattiesību ierobežojumus atteikšanās no dienesta izpildes aspektā, tai skaitā - absolūtus aizliegumus, tomēr katrā konkrētajā gadījumā likumdevējam ir jāpamato, ka šādi ierobežojumi ir ne vien nepieciešami, bet arī attaisnojami.

3. Pacifiskā pārliecība un principiāli iebildumi pret militārā dienesta izpildi ietilpst Satversmes 99. panta tvērumā, tomēr ierobežojama ir vienīgi to paušana - klusējot vai atsakoties veikt militāras darbības, kas ir pretrunā ar personas pārliecību.

4. Militārā dienesta likumā noteiktie aizliegumi atteikties no dienesta izpildes pacifisma vai principiālu iebildumu dēl neatbilst samērīguma principam un līdz ar to var būt atzīstami par Satversmes 99. panta pirmajā teikumā nostiprināto tiesību uz domas, apziņas un reliğiskās pārliecības brīvību neattaisnojamiem aizskārumiem. 